\title{
The Effectiveness of Problem Posing Learning by CTL Orientation Viewed from Knowladge, Skill, and Attitude
}

\author{
Desutri Ulantari ${ }^{1}$, Idris Harta ${ }^{2}$ \\ ${ }^{1,2}$ Universitas Negeri Yogyakarta, ${ }^{2}$ Universitas Muhammadiyah Surakarta \\ Correspondence Address; ariededevale@gmail.com
}

\begin{abstract}
This research aimed to describe: 1) the effectiveness of the use of Problem Posing Learning by CTL orientation, 2) the effectiveness of the use of CTL lessons viewed from knowledge, skills, and students' attitude, and 3) to compare which one is more effective between Problem Posing Learning by CTL orientation and CTL lessons viewed from knowledge, skills, and students' attitude. The kind of this research was quasi experiment by using pretest-posttest control group design. The population of this research was the eleventh grade students of MA NW Pancor, Lombok Timur, NTB. The sample of this research was already chosen randomly. Techniques of collecting the data were test and non-test by using research instrument of knowledge test, skills test, and students' attitude questionnaires. One sample t-test used to test the effectiveness of learning which was already used in each variable. The result of the research showed that: 1) Problem Posing Learning by CTL orientation was effective viewed from knowledge, skills and attitude students' attitude, 2) CTL was effective viewed from knowledge, skills, and students' attitude, and 3) there was no effectiveness difference between Problem Posing Learning by CTL orientation and CTL lessons viewed from knowledge, skills, and students' attitude.
\end{abstract}

Keywords: Problem Posing; CTL; Knowledge; Skills; and Students' attitude

\section{INTRODUCTION}

Curriculum 2013 is a curriculum developed to improve and balance the abilities of soft skills and hard skills in attitudes, skills and knowledge (Fadillah, 2014). The aims is that students can have the competencies that increase and develop with the level of their education so that they can influence and determine success in the next life. According to (Dehyadegary, Divsalar, Shahsavari, Nekouei, \& Sadr, 2012) that one of the major crises in the education system in many countries, especially in the developing countries is the problem of low academic achievement. One of the subject that is in the public viewed today is mathematics, according to some students, is considered a difficult and elusive material, the students are unhappy, even afraid (Ibrahim, 2018; Khamid \& Santosa, 2016). Based on (OECD, 2015) for PISA 2015, performance averages in 35 OECD countries were 490. Statistically Indonesia was far below the OECD average with the point of 386. Comparison of mathematical performance between 2012 and 2015 also did not progress significant. There are many factors that influence the low results of the PISA survey. As stated in the BERMUTU Program (Better Education through Reformed Management and Universal Teacher Upgrading) Program (Ministry of National Education, 2011), Indonesian students are generally poorly trained in solving character problems such as the PISA questions. The syllabus that is compiled generally presents learning outcome assessment instruments whose substance is less related to the context of student life and less facilitates students in expressing thought processes and arguments.

The Student learning success can not be separated from the involvement of teachers in the learning process by using various methods developed (Khamid \& Santosa, 2016). There are several types of learning methods and one of them is the Problem Posing method. the Problem 
Posing starts with problems in the questions, so in students there is a desire to know through the learning process (Nasrullah \& Marsigit, 2016). The results showed that the use of Problem Posing learning was better and had a positive effect on learning achievement (Amiluddin \& Sugiman, 2016; Muzaini, 2016; Sugito, 2014), had a significant effect on the learning outcomes of mathematics, science (Astra, Umiatin, \& Jannah, 2012; Irawati, 2014; Kadir, 2011; Panjaitan, 2018; Sudiyono, 2017; Yulianti, An'nur, \& Mustika Wati, 2014), there is an influence on the ability to understand mathematical concepts (Herawati, Siroj, \& Basir, 2010), there are influences towards critical thinking skills and mathematical communication skills (Juano \& Pardjono, 2016), can shape students' character of responsibility and communication skills (Septiani, Sukestiyarno, \& Suyitno, 2013) and increase mathematical communication skills (Astuti, 2014; Thalhah, 2014), mathematical problem solving abilities in the Problem Posing class are better (Nuraeni \& Rosyid, 2019), increasing mathematical reasoning skills (Novia, Wahyuni, \& Husna, 2017), there are increase in mathematical and more effective understanding (Ferdianto \& Ghanny, 2011), improve mathematical problem solving skills (Astriyani, 2016), improve students' mathematical proofing abilities (Hodiyanto \& Susiaty, 2018), improve student creativity (Priambodo, Listiara, \& Astuti, 2013 ) and increase the quality of learning outcomes (Rahman \& Ahmar, 2017).

The effectiveness of using Problem Posing in learning, according to the results of the research, is the effective learning (Susanti, Sukestiyarno, \& Sugiharti, 2012), and also effectively improving learning outcomes and student activities (Septina, Hartini, \& Suyidno, 2014), effective viewed of learning achievement and mathematical connection skills (Setyaningsih \& Widjajanti, 2015), effective viewed of critical thinking skills (Nugraha \& Mahmudi, 2015), effective in mathematics learning viewed of achievement of competency standards, critical thinking skills, and emotional intelligence of students (Shanti \& Abadi, 2015), effective against creative thinking skills (Permatasari, Veronica, \& Susilo, 2013), effective against problem solving abilities (Daryati, Nugraha, \& Sutarni, 2018; Fajariyah, Sukestiyarno, Masrukan, \& Junaedi, 2012; Kusnaeni \& Retnawati, 2013 ), effective viewed of mathematical communication skills (Kusnaeni \& Retnawati, 2013), effectively reviewed from HOTS (Nurina \& Retnawat i, 2015), effective viewed of ability to understand and mathematical reasoning (Falach, 2016), effective viewed of achievement of basic competencies, mathematical methods, and mathematical attitudes of students (Nasrullah \& Marsigit, 2016), effective mastery of mathematical problem solving skills (Retnowati, Fathoni, \& Chen, 2018) and effective viewed of attitudes and learning achievements (Palobo, 2016).

Elaine B. Johnson (Rusman, 2016) states contextual learning is a system that stimulates the brain to compose patterns of embody meaning. Furthermore, Elaine said that contextual learning is a learning system that fits the brain that produces meaning by linking academic content with the context of students' daily lives. In addition, (Rusman, 2016) states that learning experiences oriented to experience and applicable are more practical in nature, not interpreted as providing conceptual theoretical experiences that are not important. Because the mastery of theoretical knowledge properly by students will facilitate better applicable. 
Many previous studies using CTL, can improve the students' abilities. The results of the research included the influence of mathematical communication skills, self-confidence, and mathematics learning achievement of junior high school students (Agustyaningrum \& Widjajanti, 2013), increasing the activeness and learning outcomes of mathematics (Taurina \& Wasitohadi, 2015; Yeliherti, 2015), learning achievement and affective aspects better than direct learning models (Negara, K, \& Sujadi, 2016), improving learning outcomes in mathematics, science and social studies (Hutama, 2014; Jusmaini, 2016; Khoiriyah, Laili, \& Mahmudah, 2018; Murniati, 2016; Mustamu, 2018 ; Qisthy, Sukardi, \& Tarmudji, 2012; Ruskandi \& Ferdian, 2015; A. Wijayanti \& Wulandari, 2016; Yulindaria \& Cahyani, 2017), improving student achievement (Padri, Utari, Nurhidayah, \& Permatasari, 2012), communication skills student mathematics (Yuliani, 2015), increasing students' self-confidence in mathematics (Ibrahim, 2018), improving the quality of mathematics learning (Yenti, 2009), improving problem solving skills (Rofik, 2 015), improving understanding of concepts (Fatmasari, Zainuddin, \& An'nur, 2013; Fitria, Sumarni, \& Wusqo, 2016; Hutabarat, 2016), there is a positive and significant relationship between mathematical communication skills and self-esteem both using learning with the CTL approach (Yuniarti, Sulasmini, Rahmadhani, Rohaeti, \& Fitriani, 2018), improving writing skills (Kristiyani, 2009), improving quality of learning outcomes (Pukjiwati, 2017), improve critical thinking skills in learning Chemistry and Social Sciences (Ruskandi \& Ferdian, 2015; Tantu, 2018), have a positive effect and improve high-level thinking skills (Fayakun \& Joko, 2015), affect learning outcomes cognitive and scientific attitudes of students (Cholifah, Parmin, \& Dewi, 2016).

The effectiveness of the use of CTL in the learning process is very positive, which is effective viewed of mathematics learning achievement (Narendrati, 2017), effective on social studies learning outcomes (Wulandari \& Setyowati, 2017), effectively reviewed creative thinking and mathematical creative thinking (Pratinuari, Sugiarto, \& Pujiastuti, 2013; S, 2016), more effective than direct learning viewed of mathematical communication skills (Ratnasari \& Saefudin, 2018), very effective in achieving curriculum competencies in 2006 in Economics (Hasyim, 2011), effective viewed of achievement SK / KD and mathematical connection skills (Putri \& Abadi, 2014), effective viewed of student achievement and learning motivation (Laili, 2016), effective viewed of mathematical communication skills and learning motivation (Khamid \& Santosa, 2016), effective viewed of achievement mathematics and student learning activities towards mathematics (Nuryadi, 2014), effective viewed of achievement learn mathematics and student religiosity (T. Wijayanti \& Sugiman, 2013), effective viewed of affective learning outcomes (Rahmawati \& Harta, 2014).

The Previous research has been carried out by (Rofik, 2015) regarding the mathematics learning of the CTL model with the Problem Posing approach assisted by e-learning to improve problem solving skills. The research by (Putri \& Abadi, 2014) concerning the effectiveness of mathematics learning with the CTL and Problem Posing approaches viewed of SK / KD achievement and mathematical connection skills. Research by (Narendrati, 2017), comparison of statistical learning through the CTL approach and Posing Problem viewed of learning achievement and mathematical learning interest. The research also uses a variety of learning 
of the use of Problem Posing and CTL learning. The different of the research, the use of Problem Posing learning that is oriented to Contextual Teaching and Learning (CTL) in effectiveness is reviewed by the knowledge, skills, and attitudes students.

Based on the description and previous research, the researcher conducted a research with the title "The Effectiveness Of The Use of Problem Posing Learning by CTL Orientation Viewed from Knowladge,Skill, And Attitude ". The purpose of the reserach is to describe: 1) the effectiveness of using problem posing learning with the orientation of contextual teaching and learning, 2) the effectiveness of using contextual teaching and learning viewed of the students' knowledge, skills and attitudes, and 3) more effective comparing learning Problem Posing CTL orientation and CTL learning in the students' knowledge, skills and attitudes.

\section{THE RESEARCH METHODS}

This research is classified as quasi-experimental research. The design used in this research is a pretest-post test two treatment design. Schematically, the research design used in this research is as follows:

$\begin{array}{cccc}\text { Group I } & O_{1} & X_{1} & O_{2} \\ \text { Group II } & O_{3} & X_{2} & O_{4}\end{array}$

Description:

$\mathrm{X}_{1}$ : Group I Learning Problem Posing CTL orientation

$\mathrm{X}_{2}$ : Group II CTL Learning

$\mathrm{O}_{1}$ : Group I pretest

$\mathrm{O}_{2}$ : Group I posttest

$\mathrm{O}_{3}$ : Group II pretest

$\mathrm{O}_{4}$ : Group II posttest

The population in this research were the students of class XI IPS at NW Pancor Senior High School. Sampling is done randomly. The samples taken were class XI IPS 1 and Class XI IPS 2 which were then drawn to determine which classes were given Problem Posing learning treatment CTL orientation and which classes were given CTL learning treatment. Based on the drawing results obtained by the XI IPS 1 class, the Problem Posing learning orientation of the CTL and XI IPS 2 classes was given the CTL learning treatment.

The technique used to collect data in this research is the test and questionnaire. The test are used multiple choice tests to collect data on student mathematics learning outcomes related to students' knowledge and skills before and after being treated. Then to measure students' attitudes, non-test techniques were used in the form of questionnaires given before and after treatment. The questionnaire is the statement form / questionnaire. The alternative answers provided in the questionnaire are Strongly Agree (SS), Agree (S), Doubtful (Rg), Disagree (TS), and Strongly Disagree (STS).

The validity of the instrument in this research was obtained through content validity and construct validity. The validity of student knowledge test instruments and student skills in this research is content validity, while the validity for the student attitude questionnaires is convert validity and construct validity. To obtain validation evidence the instrument is done by asking 
for consideration of two experts (expert judgment). After the instrument is examined by the validator, the instrument is revised according to the input and instructions given by the validator. Furthermore, the instrument was tested on certain schools to obtain the results of trials which were analyzed by factors (exploratory factor analysis) on the results of the questionnaire obtained. This is intended to obtain evidence of construct validity from the questionnaire instruments that have been made. The analysis was carried out using the SPSS 21 program assistance.

Based on the results of the factor analysis of 25 questionnaires the attitude was obtained eight factors empirically. The distribution of items for each component and its comparison with the previous theoretical construct, can be seen in the following table.

Table 1. The Item Identification Based on Theory with Factor Analysis

\begin{tabular}{llcc}
\multicolumn{1}{c}{ The blue Print Based on Theory } & & \multicolumn{2}{c}{ The Blue Print Based on } \\
Factor Analysis
\end{tabular}

Then for the reliability of the test and non-test instruments according to Allen and Yen (1979: 83), estimating the reliability of the instrument can be done by calculating the reliability coefficient by using the coefficient formula alpha $(\alpha)$ that is $=\frac{N}{N-1}\left(\frac{\sigma_{x}{ }^{2}-\sum_{i=1}^{N} \sigma_{Y_{i}}{ }^{2}}{\sigma_{x}{ }^{2}}\right)$, with $\alpha$ (test reliability coefficient), $N$ (number of components / number of items), $\sigma_{x}{ }^{2}$ (varians total score), and ${\sigma_{Y}}^{2}$ (score variance for each item). The Data analysis was performed using the help of the SPSS 21 program. The results of the analysis showed that the reliability coefficients for the data pretest of students' knowledge, skills and attitudes were respectively 0,757;0,800;0,903. After obtaining the reliability coefficient, it can be interpreted by determining the Standard Error of Measurement (SEM) value. By applying the formula $M=S_{x} \sqrt{1-r_{x x^{\prime}}}$, with $S E M$ (Standar Error of Measurement), $S_{x}$ (standard deviation score), and $r_{x x^{\prime}}$ (reliability coefficient). The results of SEM calculations using SPSS 21 are as follows.

Table2. SEM Calculation Results 


\begin{tabular}{clcc}
\hline Number & Instrument & $\begin{array}{c}\text { Standart } \\
\text { Deviation }\end{array}$ & SEM \\
\hline 1 & Knowladge & 4,930 & 2,430 \\
2 & Skill & 2,281 & 1,020 \\
3 & Attitude & 14,429 & 3,871 \\
\hline
\end{tabular}

The data analyzed in this research were pretest and post-test data on students' knowledge, skills and attitudes towards mathematics. the Student scores from student knowledge tests were described as the value of student knowledge, for the results of student skills tests described as the value of student skills, then the student attitude questionnaire scores are described as data on student attitudes with categories.

The testing of the hypothesis in this reserach would be conducted using Multivariate Analyze of Variance (MANOVA), One Sample t-test, and Independent Sample t-test. But before carrying out the test, the assumption was tested before treatment (pretest) and also after treatment (post-test). The test assumptions made were normality test (multivariate and univariate) and homogeneity test (multivariate and univariate).

The normality test was used to determine the distribution of the data between the highest value to the lowest value in the sample, whether the population was normally distributed or not. The data to be tested for normality were pretest and post-test data. Multivariate Normality Test, the normality test used was the distance test for the Mahalonobis with Ms. Excel. The steps of the Mahalonobis distance test according to Johnson and Wichern were 1) Determining the deviation matrix which was the difference between the scores of each respondent and the average score of each observation variable $\left(Y_{i}-\bar{Y}_{l}\right) ; 2$ ) the determine the SSCP matrix (Sum Square and Cross Product) or matrix $W=\left(Y_{i}-\bar{Y}_{l}\right)^{T}\left(Y_{i}-\bar{Y}_{l}\right)$; 3) Determine the $S$ matrix (Covariance Variance) and the inverse of the covariance variance matrix $S^{-1}$; 4) Determine the value of $d_{i}{ }^{2}$ was the mahalanobis distance of each observation with the average vector, i.e. which was the mahalanobis distance of each observation with the average vector, i.e. $d_{i}{ }^{2}=$ $\left(Y_{i}-\bar{Y}_{l}\right) S^{-1}\left(Y_{i}-\bar{Y}_{l}\right)^{T}$ with $\left.i=1,2,3, \ldots, n ; 5\right)$ sorting $d_{i}{ }^{2}$ from the samallest value until the highest value is $\left.d_{1}{ }^{2}<d_{2}{ }^{2}<\cdots<d_{n}{ }^{2} ; 6\right)$ Determine the value $x_{0,5(p)}^{2}$ with $p$ was the high value; and 7)If around 50\% value $d_{i}{ }^{2}<x_{0,5(p)}^{2}$ it can be said that the data was multivariate in normal distribution. Meanwhile, the univariate normality test was carried out using the SPSS 21 program assistance. This test was carried out using the Kolmogorov-Smirnov test. The success criteria used are the data normally univariate if the significance value is higher than 0.05 .

Furthermore, the homogeneity test was conducted to determine the similarity of the variance-covariance matrix of the dependent variable in the research. the homogeneity test of the covariance matrix, this test was carried out using the Box's M test with the help of SPSS 21 . The testing criteria, if the significance value was higherr than the 0.05 significance level, then the data was said to have fulfilled the assumption of multivariate homogeneity. Meanwhile, the variance homogeneity test was carried out using the Levene Statistic test with the help of SPSS 21. The testing criteria were getting the data fulfilled of the assumption of univariate homogeneity if the significance value was higher than 0.05 . 
After the assumption test was fulfilled, it was continued by conducting the hypothesis test. The first hypothesis test was the test of learning effectiveness. This effectiveness test was conducted to determine the effectiveness of learning used in this research. As for the learning used in the research was problem posing learning orientation contextual teaching and learning and learning contextual teaching and learning viewed of aspects of knowledge, skills, and attitudes of students towards mathematics. the learning effectiveness criteria of each of the related variables are (a) the average student's knowledge was at least 65; (b) the average student skill score was at least 65; and (c) the average score of the questionnaire of students' attitudes towards mathematics was in the moderate category which was more than 67 . Testing of this hypothesis was done using one sample t-test. Tatsouka (1971: 77), the hypothesis test formula used was $t=\frac{\bar{X}-\mu_{0}}{\frac{S}{\sqrt{n}}}$, with $\bar{X}$ (average value obtained), $\mu_{0}$ (hypothesized value), $S$ (sample standard deviation), and $n$ (amount of sample members). The test criteria in the one sample ttest test were $H_{0}$ ejected if the significance value is smaller than 0,05 .

The second hypothesis test was to test the difference in effectiveness between the two groups. The analysis of the differences in effectiveness was carried out to see whether there were differences in the initial conditions between the two groups. The Analysis of data before treatment aims to see whether there were differences in the initial conditions between the two groups. While the data analysis after treatment aims to see whether there was the difference in effectiveness between the two groups after being given treatment. The test statistics used to test the hypothesis above were the Mutivariat $T^{2}$ Hotteling's (MANOVA). test. The formula used was $T^{2}=\frac{n_{1} n_{2}}{n_{1}+n_{2}}\left(\overline{y_{1}}-\overline{y_{2}}\right)^{\prime} S^{-1}\left(\overline{y_{1}}-\overline{y_{2}}\right)$, with $T^{2}$ (Hotelling's Trace), $n_{1}$ (many subjects in the first group), $n_{2}$ (many subjects in the second group), $\overline{y_{1}}-\overline{y_{2}}$ (mean vector), and $S^{-1}$ (inverse matrix covariance). After obtaining the value $T^{2}$ Hotteling's, then the value was transformed to obtain the distribution value of F. Stevens (2009: 151), the formula used was $F=\frac{n_{1}+n_{2}-p-1}{\left(n_{1}+n_{2}-2\right) p} T^{2}$, where $p$ was the number of dependent variables. The testing criteria were $\mathrm{H}_{0}$ rejected if the significance value was less than 0.05 . If there were differences in the initial conditions between the two groups then to find out the difference in the effectiveness of learning between the two groups carried out using pretest and post-test data for the MANCOVA test where the pretest as the covariate. However, if the initial conditions of the two groups were the same, then to find out the difference in effectiveness of the two groups, the MANOVA test was used and the data analyzed was only post-test data.

The third hypothesis test in the research was the comparison of the effectiveness of learning. The comparative test of learning effectiveness in this section was based on the results of the MANOVA test. If the results of the MANOVA test showed that there were differences between the two groups, the test was continued to find out which learning is more effective. The statistics used to test the hypothesis were univariate tests using the Benferroni criteria. The

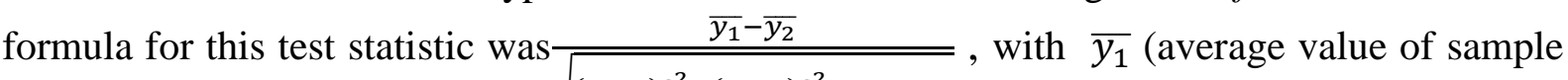
$\sqrt{\frac{\left(n_{1}-1\right) S_{1}^{2}+\left(n_{2}-1\right) S_{2}^{2}}{n_{1}+n_{2}-2}\left(\frac{1}{n_{1}}+\frac{1}{n_{2}}\right)}$

I), $\overline{y_{2}}$ (avarage value of samplel II), $S_{1}^{2}$ (varians sampel I), $S_{2}^{2}$ (varians sampel II), $n_{1}$ (many 
members of sample I), and $n_{2}$ (many members of sample II). The testing criteria for the test statistics above were $\mathrm{H}_{0}$ is rejected if $t_{\text {hitung }} \geq t_{\left(\frac{\alpha}{p}, n_{1}+n_{2}-2\right)}$.

\section{THE RESULTS OF THE RESEARCH AND THE DISCUSSION}

The first step before testing the formulated hypothesis was to test the initial data. The data used included the pretest of students' knowledge, skills and attitudes towards mathematics. the test was conducted using multivariate analysis which aimed to see whether there were differences in the initial conditions in the two experimental groups viewed of students' knowledge, skills, and attitudes towards mathematics. If both groups were same (there is no difference in the average of the three aspects of observation), the data that would be used to test the effectiveness and which effective group was the data after treatment only. However, if the initial conditions of the two groups were different then data before and after treatment were used to test which group is more effective. Before carrying out multivariate analysis there were several assumptions that must be fulfilled.

Some assumption tests had to be fulfilled before carrying out multivariate analysis, namely 1) the population was multivariate normal distribution; 2) there were similarities in the covariance matrix; 3) observations made were mutually free or random. In the research, the third assumption was considered fulfilled because the selection of samples in the research was mutually independent. The following were the results of testing the assumption of multivariate normality and the assumption of homogeneity of the covariance matrix.

The multivariate normality assumption test was carried out to find out whether the samples taken were from normally distributed populations. The normality used is the distance of the Mahalonobis by using the help of the Microsoft Office Excel 2013 program. After the normality test was obtained the information that before the treatment the percentage value $d_{i}{ }^{2}$ was less than 2,366 for the Problem Posing class CTL orientation was 50\% and for CTL class was $52.38 \%$. Percentage of value $d_{i}{ }^{2}$ both classes approach $50 \%$, It showed that the data before treatment came from the population that was normally distributed. In other words, the assumption of multivariate normality for data before treatment was fulfilled.

Next, the assumption of homogeneity was carried out to determine whether the variances in the population were the same or not. The homogeneity test in the research was carried out using the Box's $M$ test with the help of SPSS 21 software. In summary the results of the test homogeneity of the variance-covariance matrix obtained were that Box's $M$ significance values in the pre-treatment data were higher than $0.05,0.201$. It showed that the assumption of multivariate homogeneity was fulfilled. After assumption tests were fulfilled, testing was continued to find out whether the two experimental groups were from the same initial conditions or not viewed of students' knowledge, skills, and attitudes towards mathematics. The data analysis would use MANOVA. After calculating the data before treatment using SPSS 21, the results of $F=2.684$ and $\mathrm{Sig}=0.060$ were obtained. It showed that there was no difference in the average data on pretest knowledge, skills, and attitudes of the students towards mathematics between the two experimental groups. Or in other words the initial conditions of the two classes for all aspects measured were the same. 
After the assumption test was fulfilled, then the test would be carried out to determine the effectiveness of learning in both experimental classes for each variable. The calculation was done by using SPSS 21 on the value of students' knowledge, skills and attitudes towards mathematics obtained by the value $t$ as in the following table.

Table 3. The Effectiveness of Problem Posing CTL Orientation viewed from Student Knowledge, Skills, and Attitudes

\begin{tabular}{ccccccc}
\hline \multicolumn{7}{c}{ One-Sample Test } \\
& \multicolumn{7}{c}{ Test Value $=65$} \\
& \multirow{2}{*}{$t$} & $d f$ & Sig. (2-tailed) & $\begin{array}{c}\text { Mean } \\
\text { Difference }\end{array}$ & \multicolumn{2}{c}{$\begin{array}{c}\text { 95\% Confidence Interval of the } \\
\text { Difference }\end{array}$} \\
\cline { 2 - 5 } & & & & & Lower & Upper \\
\hline P1 & 5.607 & 21 & 0.001 & 12.55682 & 7.8995 & 17.2141 \\
K1 & 16.364 & 21 & 0.001 & 24.54545 & 21.4261 & 27.6648 \\
S1 & 4.634 & 21 & 0.001 & 12.12227 & 6.6818 & 17.5628 \\
\hline
\end{tabular}

Table 4. The Effectiveness of CTL Learning Viewed from Knowledge,Skills, and Attitudes of Students

\begin{tabular}{ccccccc}
\hline \multicolumn{7}{c}{ One-Sample Test } \\
& \multicolumn{7}{c}{ Test Value $=65$} \\
& \multirow{7}{c}{$T$} & $d f$ & Sig. (2-tailed) & $\begin{array}{c}\text { Mean } \\
\text { Difference }\end{array}$ & \multicolumn{2}{c}{$\begin{array}{c}\text { 95\% Confidence Interval of the } \\
\text { Difference }\end{array}$} \\
\cline { 6 - 7 } & & & & Lower & Upper \\
\hline P2 & 3.433 & 20 & .003 & 7.61905 & 2.9899 & 12.2482 \\
K2 & 13.642 & 20 & 0.001 & 20.71429 & 17.5470 & 23.8815 \\
S2 & 3.224 & 20 & .004 & 8.17476 & 2.8864 & 13.4631 \\
\hline
\end{tabular}

Based on the table above it could be seen that the significance value was for all aspects if divided by two values smaller than 0.05. It showed that the Problem Posing learning CTL orientation was effective of aspects of students' knowledge, skills and attitudes. The CTL learning, CTL learning was effective viewed of the aspects of students' knowledge, skills and attitudes.

The next hypothesis test was to test which learning was more effective between the Problem Posing class orientation CTL and the Contextual Teaching and Learning class. In the multivariate analysis for the data before treatment, the results showed that the initial conditions of the two classes were the same. Therefore, which class testing was more effective only used data after treatment. The Data after treatment included post-test data on the students' knowledge, skills and attitudes towards mathematics. Testing which class hypotheses were more effective using the MANOVA test. But before the MANOVA test was done, the data after treatment had to meet the assumptions of multivariate normality and homogeneity of the covariance matrix. 
After the assumption test was fulfilled, the test was continued by testing to find out whether there were differences in the average data on the posttest data of students' knowledge, skills and attitudes towards mathematics. After calculating using SPSS 21 the $F$ significance value was obtained as shown in the following table:

Table 5. Multivariat Test Data After Treatment

\begin{tabular}{llccccc}
\hline \multicolumn{7}{c}{ Multivariate Tests } \\
& Effect & Value & $F$ & $\begin{array}{c}\text { Hypothesis } \\
\text { df }\end{array}$ & $\begin{array}{c}\text { Error } \\
\text { df }\end{array}$ & Sig. \\
\hline \multirow{3}{*}{ Intercept } & Pillai's Trace & .994 & $2231.408^{\mathrm{b}}$ & 3.000 & 39.000 & .000 \\
& Wilks' Lambda & .006 & $2231.408^{\mathrm{b}}$ & 3.000 & 39.000 & .000 \\
& Hotelling's Trace & 171.647 & $2231.408^{\mathrm{b}}$ & 3.000 & 39.000 & .000 \\
& Roy's Largest Root & 171.647 & $2231.408^{\mathrm{b}}$ & 3.000 & 39.000 & .000 \\
\hline \multirow{3}{*}{ KLP } & Pillai's Trace & .078 & $1.104^{\mathrm{b}}$ & 3.000 & 39.000 & .359 \\
& Wilks' Lambda & .922 & $1.104^{\mathrm{b}}$ & 3.000 & 39.000 & .359 \\
& Hotelling's Trace & .085 & $1.104^{\mathrm{b}}$ & 3.000 & 39.000 & .359 \\
& Roy's Largest Root & .085 & $1.104^{\mathrm{b}}$ & 3.000 & 39.000 & .359 \\
\hline
\end{tabular}

a. Design: Intercept + KLP

b. Exact statistic

Based on the table it could be seen that the significance value of $F$ was Higher than 0.05 , which was 0.359. It showed that therewas no difference in the average data on post-test knowledge, skills, and attitudes of students in the two experimental classes. In other words there was no difference in effectiveness between classes that used learning processes posing orientation to contextual teaching and learning with classes that use learning contextual teaching and learning. Therefore, researchers did not need to carry out further tests to determine which learning was more effective.

In this research were three hypotheses. Based on the results of hypothesis testing were two hypotheses fulfilled, namely 1) problem posing learning orientation of contextual teaching and learning effective viewed of students 'knowledge, skills and attitudes and 2) contextual teaching and learning was effective in viewed of students' knowledge, skills and attitudes. While the third hypothesis was not fulfilled because there was no difference in effectiveness between the two learning.

Based on the results of the first hypothesis test for knowledge variables obtained t value of 5.607 with the synergy level of 0.001 . It showed that problem posing learning with contextual teaching and learning oriented was effective viewed of student knowledge. It was because problem posing learning with the orientation of contextual teaching and learning involved students directly. The student involvement provided opportunities for students to be more skilled in determining which concepts would be used in the problem at hand. Supported by research results by (Palobo, 2016) problem posingwas effective viewed of learning achievement. Then, the results of the first hypothesis test for the skill variable obtained The $t$ value of 16,364 with the significance level of 0,001. It showed that problem posing learning with the orientation of contextual teaching and learning was effective viewed of student skills. 
It was because the use of problem posing learning with the orientation of contextual teaching and learning provides opportunities for students to ask related questions, then The students were asked to find solutions to the questions they had made. In addition, the conditions that arose make learning more meaningful. The results of the reserach (Septiani et al., 2013) support that problem posing could improve students' mathematical communication skills. In accordance with the results of the research (Retnowati et al., 2018) that problem posing learning was effective in mastering mathematical problem solving skills. In addition, the results of the first hypothesis test for attitudinal variables obtained $t$ value of 4.634 with the significance level of 0.001 . It showed that problem posing learning with the orientation of contextual teaching and learning was effective in viewed of student attitudes. It was due to one of them because of the conditions that arose when the learning. Where problem posing learning with the orientation of contextual teaching and learning involved students directly, gives the opportunity to make questions, then find solutions to these problems. It made students more confident, more confident in themselves because they were able to find solutions to the questions they had made so that it would also affect students' attitudes towards mathematics. It was reinforced by the results of research by (Septiani et al., 2013) could shape the character of responsibility and improve it. Then the results of the research (Nasrullah \& Marsigit, 2016) support the effective problem posing viewed of students' mathematical attitudes. The results of the research obtained (Palobo, 2016) showed that problem posing was effective in viewed of learning attitudes.

Based on the results of the second hypothesis test for the knowledge variable, the value of $t$ is 3,433 with the synergy level of 0,003 . It showed that learning contextual teaching and learning was effective viewed of the student knowledge. It was because learning experiences that were oriented on experience and applicative abilities were more practical, but did not mean the provision of conceptual theoretical experiences was not important. Because the mastery of theoretical knowledge properly by students would facilitate better applicative abilities. In accordance with the results of research by (Laili, 2016; Narendrati, 2017; Nuryadi, 2014; T. Wijayanti \& Sugiman, 2013) through CTL effective viewed of learning achievement in mathematics. Furthermore, supported by research (Cholifah et al., 2016) through CTL had the effect on students' cognitive learning outcomes. In contrast to the results of the research (Rahmawati \& Harta, 2014), CTL was not effective viewed of cognitive learning outcomes. Then, the results of the second hypothesis test for the student skill variable obtained the $t$ value of 13.652 with the significance level of 0.001 . It showed that learning contextual teaching and learning was effective in viewed of student skills. It was because contextual teaching and learning was directly related to the real world that develops and occurs in the environment around students so students were able to connect and apply the competencies of learning outcomes to their daily lives. Supported by the results of research by (Kristiyani, 2009) that through $C T L$ could improve writing skills. Then the results of research by (Ruskandi \& Ferdian, 2015; Tantu, 2018) through CTL could improve students' critical thinking skills. In addition, the results of hypothesis testing for attitudinal variables obtained t value of 3.224 with the significance level of 0.004 . It showed that learning contextual teaching and learning was 
effective in viewed of student attitudes. Learning contextual teaching and learning that related directly to students 'real world problems would certainly influence students' attitudes towards mathematics. It was supported by research conducted by (Yenti, 2009). It was explained that $C T L$ was one of the learning approaches that could improve the quality of learning, could be applied to all material not only social but also scientific. The characteristic of this learning was that the students immediately got their own experience in the learning process, so that learning was more meaningful. The results of the research were in accordance with the research (Rahmawati \& Harta, 2014) also showed that CTL was effective in viewed of the attitude of learning mathematics. Also supported by the results of research by (Ibrahim, 2018) that CTL increases students' confidence in mathematics and research by (Cholifah et al., 2016) that CTL could affect the scientific attitude of students.

It showed that learning contextual teaching and learning was effective in viewed of student skills. It was because contextual teaching and learning was directly related to the real world that developed and occurs in the environment around students so the students were able to connect and apply the competencies of learning outcomes to their daily lives. Supported by the results of research by (Kristiyani, 2009) that through CTLcould improve writing skills. Then the results of research by (Ruskandi \& Ferdian, 2015; Tantu, 2018) through CTL could improve students' critical thinking skills. In addition, the results of hypothesis testing for attitudinal variables were obtained $t$ value of 3.224 with the significance level of 0.004 . It showed that learning contextual teaching and learning was effective in viewed of the student attitudes. The Learning contextual teaching and learning that related directly to students 'real world problems would certainly influence students' attitudes towards mathematics. It was supported by research conducted by (Yenti, 2009). It was explained that $C T L$ was one of the learning approaches that could improve the quality of learning, could be applied to all material not only social but also scientific. The characteristic of this learning was that students immediately got their own experience in the learning process, so that learning was more meaningful. The results of the research were in accordance with the research (Rahmawati \& Harta, 2014) also showed that CTL was effective in viewed of the attitude of learning mathematics. Also supported by the results of research by (Ibrahim, 2018) that CTL increases students' tendency in the mathematics and research by (Cholifah et al., 2016) that CTL could affect the scientific attitude of students.

\section{CONCLUSION AND SUGGESTION}

Based on the results of testing the hypothesis and the previous discussion it was concluded that Problem Posing learning CTL orientation and CTL learning was effective viewed of students' knowledge, skills and attitudes. Then, there was no difference in effectiveness between Problem Posing learning CTL orientation and CTL learning viewed of students' knowledge, skills and attitudes towards mathematics.

Based on the findings obtained, the suggestions that can be conveyed by the teacher can apply Problem Posing learning to $C T L$ orientation and $C T L$ learning as learning options were 
applied in the classroom. The thing that must be considered is the time management so that learning can go as planned.

\section{REFERENCE}

Agustyaningrum, N., \& Widjajanti, D. B. (2013). Pengaruh Pendekatan CTL dengan Setting Kooperatif Tipe Kancing Gemerincing terhadap Kemampuan Komunikasi Matematis , Kepercayaan Diri, dan Prestasi Belajar Matematika Siswa SMP. PYTHAGORAS: Jurnal Pendidikan Matematika, 8(2), 171-180.

Amiluddin, R., \& Sugiman, S. (2016). Pengaruh Problem Posing dan PBL Terhadap Prestasi Belajar, dan Motivasi Belajar Mahasiswa Pendidikan Matematika. Jurnal Riset Pendidikan Matematika, 3(1), 100-108.

Astra, I. M., Umiatin, \& Jannah, M. (2012). Pengaruh Model Pembelajaran Problem Posing Tipe Pre-Solution Posing Terhadap Hasil Belajar Fisika dan Karakter Siswa Sma. Jurnal Pendidikan Fisika Indonesia, 8, 135-143.

Astriyani, A. (2016). Peningkatan Kemampuan Pemecahan Masalah Peserta Didik Dengan Penerapan Model Pembelajaran Problem Possing. FIBONACCI, 2(1), 23-30.

Astuti. (2014). Pengaruh Pendekatan Problem Posing dengan Model Pembelajaran Kooperatif Tipe Stad terhadap Kemampuan Komunikasi Matematis Siswa Kelas Xii Sma Negeri 1 Salo Kabupaten Kampar. Jurnal PAUD Tambusai, 1(1), 1-11.

Cholifah, N., Parmin, \& Dewi, N. R. (2016). Pengaruh Pendekatan Contextual Teaching and Learning (CTL) Berbasis Eksperimen Terhadap Hasil Belajar Kognitif dan Sikap Ilmiah. USEJ, 5(3), 1343-1353.

Daryati, D., Nugraha, \& Sutarni, N. (2018). Pengaruh Penggunaan Metode Problem Posing terhadap Kemampuan Memecahkan Masalah. JPIS, 27(1), 31-42.

Dehyadegary, E., Divsalar, K., Shahsavari, F. P., Nekouei, S., \& Sadr, A. J. (2012). Academic engagement as a mediator in relationship between emotional intelligence and academic achievement among adolescents in Kerman-Iran. Journal of American Science, 8(9), 823832.

Fadillah. (2014). Implementasi Kurikulum 2013. (A.-R. MEDIA, Ed.). Yogyakarta.

Fajariyah, N. I., Sukestiyarno, Y., Masrukan, \& Junaedi, I. (2012). Keefektifan Implementasi model Pembelajaran Problem Posing dan Creative Problem Solving Terhadap Kemampuan Pemecahan Masalah Peserta Didik di Smp N 1 Tengaran. UJME, 1(2252).

Falach, H. N. (2016). Perbandingan Keefektifan Pendekatan Problem Solving dan Problem Posing dalam Pembelajaran Matematika pada Siswa SMP. PYTHAGORAS: Jurnal Pendidikan Matematika, 11(2), 136-148.

Fatmasari, D., Zainuddin, \& An'nur, S. (2013). Aplikasi Pendekatan Contextual Teaching and Learning (CTL) untuk Meningkatkan Pemahaman Konsep Siswa. Berkala Ilmiah Pendidikan Fisika, 1(1), 70-81. 
Fayakun, M., \& Joko, P. (2015). Efektivitas Pembelajaran Fisika Menggunakan Model Kontekstual (CTL) Dengan Metode Predict, Observe, Explain Terhadap Kemampuan Berpikir Tingkat Tinggi. Jurnal Pendidikan Fisika Indonesia, 11(1), 49-58.

Ferdianto, F., \& Ghanny. (2011). Meningkatkan Kemampuan Pemahaman Matematis Siswa Melalui Problem Posing. Jurnal Euclid, 1(1), 47-54.

Fitria, M., Sumarni, W., \& Wusqo, I. U. (2016). Pengaruh Pendekatan CTL Berbasis Sets Terhadap Pemahaman Konsep dan Karakter Siswa. USEJ, 5(2), 1298-1307.

Hasyim, M. (2011). Pencapaian Standar Kompetensi Dalam Kurikulum 2006 Pada Mata Pelajaran Ekonomi Melului Pendekatan Kontekstual (Contextual Teaching And Learning) di Sma Negeri 11 Semarang. Jurnal Pendidikan Ekonomi Dinamika Pendidikan, VI(1), 45-61.

Herawati, O. D. P., Siroj, R., \& Basir, H. M. D. (2010). Pengaruh Pembelajaran Problem Posing Terhadap Kemampuan Pemahaman Konsep Matematika Siswa Kelas XI IPA SMA Negeri 6 Palembang. Jurnal Pendidikan Matematika, 4(1), 70-80.

Hodiyanto, \& Susiaty, U. D. (2018). Peningkatan Kemampuan Pembuktian Matematis Melalui Model Pembelajaran Problem Posing. MaPan : Jurnal Matematika Dan Pembelajaran, 6(1), 128-137.

Hutabarat, L. M. (2016). Upaya Meningkatkan Pemahaman Soal Cerita Dalam Pelajaran Matematika Melalui Metode CTL pada Siswa Kelas X-1 di SMA Negeri 1 Tebing Tinggi. Jurnal Handayani, 5(2), 130-143.

Hutama, F. S. (2014). Pengaruh Model PBL melalui Pendekatan CTL terhadap Hasil Belajar IPS. Jurnal Pendidikan Humaniora, 2(1), 75-83.

Ibrahim, M. (2018). Peningkatan Kepercayaan Diri Siswa Terhadap Matematika Dengan Menggunakan Pendekatan CTL (React). TATSQIF: Jurnal Pemikiran Dan Penelitian Pendidikan, 16(1), 55-77.

Irawati, R. K. (2014). Pengaruh Model Problem Solving dan Problem Posing serta Kemampuan Awal terhadap Hasil Belajar Siswa. Jurnal Pendidikan Sain, 2(4), 184-192.

Juano, A., \& Pardjono. (2016). Pengaruh Pembelajaran Problem Posing Terhadap Kemampuan Berpikir Kritis dan Komunikasi Matematis Siswa Kelas V SD. Jurnal Prima Edukasia, 4(1), 46-53.

Jusmaini. (2016). Upaya Peningkatan Hasil Belajar Soal Cerita Melalui Pendekatan Contextual Teaching and Learning (CTL) Pada Siswa Kelas III Sekolah Dasar Negeri 07 Batang Anai. Jurnal Konseling Dan Pendidikan, 4(2), 67-73.

Kadir. (2011). Impelementasi Pendekatan Pembelajaran Problem Posing dan Pengaruhnya Terhadap Hasil Belajar Matematika. Jurnal Pendidikan Dan Kebudayaan, 17(2), 203214.

Kemdiknas. (2011). BERMUTU (Better Education through Reformed Management and Universal Teacher Upgrading). Jakarta: Dirjen PMPTK. 
Khamid, A., \& Santosa, R. H. (2016). Keefektifan Pendekatan PBL dan CTL Ditinjau dari Komunikasi Matematis dan Motivasi Belajar Siswa SMP. PYTHAGORAS: Jurnal Pendidikan Matematika, 11(2), 111-122.

Khoiriyah, B., Laili, N., \& Mahmudah, M. (2018). Pendekatan Contextual Teaching And Learning (CTL) untuk Meningkatkan Hasil Belajar Akidah Akhlak. AL-MUDARRIS, 1(2).

Kristiyani, A. (2009). Penerapan Pendekatan Kontekstual untuk Meningkatkan Keterampilan Menulis Laporan Siswa Kelas VIII SMP. LITERA, 8(1), 1-10.

Kusnaeni, \& Retnawati, H. (2013). Problem Posing dalam Setting Kooperatif Tipe TAI Ditinjau dari Kemampuan Komunikasi dan Pemecahan Masalah. PYTHAGORAS: Jurnal Pendidikan Matematika, 8(1), 33-43.

Laili, H. (2016). Keefektifan Pembelajaran dengan Pendekatan CTL dan PBL Ditinjau dari Motivasi dan Prestasi Belajar Matematika Siswa. PYTHAGORAS: Jurnal Pendidikan Matematika, 11(1), 25-34.

Murniati. (2016). Peningkatan Hasil Belajar Luas Bangun Datar Melalui Pendekatan Contextual Teaching and Learning (CTL) pada Siswa Kelas III Sdn 31 Lubuk Alung. Jurnal Konseling Dan Pendidikan, 4(1), 67-73.

Mustamu, B. (2018). Penerapan Model Pembelajaran Contextual Teaching and Learning dengan Pendekatan Tim Ahli untuk Meningkatkan Hasil Belajar Siswa. Jurnal Bimbingan Dan Konseling Terapan, 2(2), 197-210.

Muzaini, M. (2016). Pengaruh Pendekatan Problem Posing Terhadap Prestasi Belajar Matematika Siswa Berdasarkan Gaya Kognitif. Beta: Jurnal Tadris Matematika, 9(2), $161-179$.

Narendrati, N. (2017). Komparasi Pembelajaran Statistika Melalui Pendekatan CTL dan Problem-Posing Ditinjau dari Prestasi Belajar dan Minat Belajar Matematika. Jurnal Riset Pendidikan Matematika, 4(1), 67-77.

Nasrullah, A., \& Marsigit, M. (2016). Keefektifan Problem Posing dan Problem Solving Ditinjau dari Ketercapaian Kompetensi, Metode, dan Sikap Matematis. PYTHAGORAS: Jurnal Pendidikan Matematika, 11(2), 123-135.

Negara, H. R. P., K, T. A., \& Sujadi, I. (2016). Eksperimentasi Model Pembelajaran Kooperatif Tipe Jigsaw dengan Pendekatan CTL Terhadap Prestasi Belajar Dan Aspek Afektif Siswa Ditinjau dari Kemampuan Spasial Siswa. TATSQIF: Jurnal Pemikiran Dan Penelitian Pendidikan, 14(2), 121-142.

Novia, C. E., Wahyuni, R., \& Husna, N. (2017). Efektivitas Model Problem Posing untuk Meningkatkan Kemampuan Penalaran Matematis Siswa pada Materi Teorema Pythagoras Kelas VIII Smp Negeri 12 Singkawang. Jurnal Pendidikan Matematika Indonesia, 2(2), 78-83.

Nugraha, T. S., \& Mahmudi, A. (2015). Keefektifan Pembelajaran Berbasis Masalah dan Problem Posing Ditinjau dari Kemampuan Berpikir Logis dan Kritis. Jurnal Riset Pendidikan Matematika, 2(1), 107-120. 
Nuraeni, Z., \& Rosyid, A. (2019). Pengaruh Model Pembelajaran Index Card Match ( ICM ) dengan Problem Posing Berbantuan Software MATLAB terhadap Kemampuan Pemecahan Masalah. Jurnal Elemen, 5(1), 12-22.

Nurina, D. L., \& Retnawati, H. (2015). Keefektifan Pembelajaran Menggunakan Pendekatan Problem Posing dan Pendekatan Open-Ended Ditinjau Dari HOTS. PYTHAGORAS: Jurnal Pendidikan Matematika, 10(2), 129-136.

Nuryadi. (2014). Keefektifan Pendekatan CTL dan PPM Pembelajaran Matematika Metode GTG Ditinjau Keaktifan dan Prestasi Siswa. PYTHAGORAS: Jurnal Pendidikan Matematika, 9(1), 22-30.

OECD. (2015). Mathematics performance (PISA) (indicator). https://doi.org/doi: $10.1787 / 04711$ c74-en

Padri, I. M., Utari, S., Nurhidayah, F., \& Permatasari, I. (2012). Efektivitas Penggunaan Peta Konsep Dalam Pembelajaran Contextual Teaching and Learning (CTL) untuk Meningkatkan Prestasi Belajar Siswa. Jurnal Pengajaran MIPA, 17(2), 219-225.

Palobo, M. (2016). Keefektifan Pendekatan Problem Posing dan Problem Solving Dalam Pembelajaran Kalkulus II. Jurnal Riset Pendidikan Matematika, 3(2), 234-244.

Panjaitan, S. (2018). Penerapan Metode Problem Posing untuk Meningkatkan Aktivitas dan Hasil Belajar Siswa Mata Pelajaran IPA Kelas IV SD 165727 Tebing Tinggi. Elementary School Journal, 8(1), 89-98.

Permatasari, G. A., Veronica, R. B., \& Susilo, B. E. (2013). Keefektifan Pembelajaran Problem Posing dengan Pendekatan PMRI Terhadap Kemampuan Berpikir Kreatif Siswa. UJME, 2(1).

Pratinuari, K., Sugiarto, \& Pujiastuti, E. (2013). Keefektifan Pendekatan Open-Ended Dengan Pembelajaran Kontekstual Terhadap Kemampuan Berpikir Kreatif. UJME, 2(1).

Priambodo, B., Listiara, A., \& Astuti, T. P. (2013). Pengaruh Dari Problem Posing Method Terhadap Kreativitas Verbal Siswa SMP Kelas VII. Jurnal Psikologi Undip Vol.12, 12(2), 109-120.

Pukjiwati. (2017). Upaya Meningkatkan Aktivitas Hasil Belajar Siswa pada Materi Pecahan Dengan Pendekatan Contextual Teaching and Learning Kelas IV SDN Sumur 03. Jurnal Refleksi Edukatika, 7(2).

Putri, R. O. P. E., \& Abadi, A. M. (2014). Keefektifan Pembelajaran Matematika dengan Pendekatan CTL dan Problem Posing Ditinjau dari Ketercapaian SK dan Kemampuan Koneksi Matematik. Pythagoras: Jurnal Pendidikan Matematika, 9(1), 79-89.

Qisthy, F. M. A., Sukardi, F., \& Tarmudji, T. (2012). Efektivitas Pendekatan Contextual Teaching and Learning (Ctl) Pokok Bahasan Permintaan, Penawaran, dan Terbentuknya Harga Pasar Terhadap Peningkatan Hasil Belajar Siswa Kelas VIII SMP Negeri 5 Cilacap Tahun Pelajaran 2011/2012. EEAJ, 1(2).

Rahman, A., \& Ahmar, A. S. (2017). Problem Posing of High School Mathematics Based on 
Their Cognitive Style. Educational Process: International Journal ISSN, 6(1), 7-23. https://doi.org/10.22521/edupij.2017.61.1

Rahmawati, Y., \& Harta, I. (2014). Keefektifan Pendekatan Open-Ended dan CTL Ditinjau Dari Hasil Belajar Kognitif dan Afektif. Jurnal Riset Pendidikan Matematika, 1(1), 113126.

Ratnasari, S. F., \& Saefudin, A. A. (2018). Efektivitas Pendekatan Contextual Teaching and Learning (CTL) Ditinjau Dari Kemampuan Komunikasi Matematika Siswa. MaPan: Jurnal Matematika Dan Pembelajaran, 6(1), 119-128.

Retnowati, E., Fathoni, Y., \& Chen, O. (2018). Mathematics Problem Solving Skill Acquisition: Learning By Problem Posing Or By Problem Solving. Cakrawala Pendidikan, (1), 1-10.

Rofik, A. (2015). Pembelajaran Matematika Model Contextual Teacing and Learning dengan Pendekatan Problem Posing Berbantuan E- Learning Materi Dimensi Tiga Kelas X untuk Meningkatkan Kemampuan Pemecahan Masalah. Jurnal Euclid, 2(2), 352-358.

Ruskandi, K., \& Ferdian, Y. (2015). Pendekatan Contextual Teaching and Lerning untuk Meningkatkan Keterampilan Berpikir Kritis Siswa. Metodik Didaktik, 10(1), 69-77.

Rusman. (2016). Model-model pembelajaran: Mengembangkan profesionalitas guru. Jakarta: PT Raja Grafindo Persada.

S, Y. R. E. (2016). Efektivitas Pendekatan Open-Ended dan CTL Ditinjau Dari Berpikir Kreatif Siswa Kelas VII. Aksioma, 5(1), 13-24.

Septiani, M. D., Sukestiyarno, \& Suyitno, A. (2013). Pembentukan Karakter dan Komunikasi Matematika Melalui Model Problem Posing Berbantuan Scaffolding Materi Segitiga. Kreano, Jurnal Matematika Kreatif-Inovatif, 4(1), 41-49.

Septina, H., Hartini, S., \& Suyidno. (2014). Penerapan Model Pembelajaran Kooperatif Dengan Pendekatan Problem Posing untuk Meningkatkan Hasil Belajar dan Aktivitas Siswa. Berkala Ilmiah Pendidikan Fisika, 2(1), 62-69.

Setyaningsih, E., \& Widjajanti, D. B. (2015). Keefektifan Pendekatan Problem posing Ditinjau dari Prestasi Belajar, Kemampuan Koneksi Matematis, dan Disposisi Matematis. PYTHAGORAS: Jurnal Pendidikan Matematika, 10(1), 28-37.

Shanti, W. N., \& Abadi, A. M. (2015). Keefektifan Pendekatan Problem Solving dan Problem Posing Dengan Setting Kooperatif Dalam Pembelajaran Matematika. Jurnal Riset Pendidikan Matematika, 2(1), 121-134.

Sudiyono. (2017). Peningkatan Hasil Belajar Bilangan Berpangkat Dengan Model Problem Posing Pada Siswa Kelas IX SMP Negeri Satu Atap Pesanggrahan 2 Batu. JINoP (Jurnal Inovasi Pembelajaran), 3(2), 639-648.

Sugito. (2014). Peningkatan Prestasi Belajar IPA Materi Kalor Dengan Problem Posing Berpasangan Kelas VIIC SMP N 3 Bawen. Phenomenon, 4(2), 79-94.

Susanti, E. L., Sukestiyarno, Y., \& Sugiharti, E. (2012). Efektivitas Pembelajaran Matematika 
Dengan Metode Problem Posing Berbasis Pendidikan Karakter. UJME, 1(1).

Tantu, Y. R. P. (2018). Penerapan Pembelajaran Kontekstual untuk Meningkatkan Kemampuan Berpikir Kritis Siswa Kelas 11 pada Pelajaran Kimia di UPH College. POLYGLOT, 14(2), 209-222.

Taurina, N. D., \& Wasitohadi. (2015). Upaya Peningkatan Keaktifan Dan Hasil Belajar Matematika Melalui Pendekatan Contextual Teaching and Learning (CTL) Berbantuan Alat Peraga pada Siswa Kelas 5 Sdn Lodoyong 03 - Ambarawa Tahun Pelajaran 2013/2014. Scholaria, 5(2), 15-35.

Thalhah, S. Z. (2014). Peningkatan Kemampuan Komunikasi Matematika Melalui Pembelajaran Dengan Pendekatan Problem Posing Pada Siswa Kelas X6 MAN Pinrang. MaPan : Jurnal Matematika Dan Pembelajaran, 2(1), 86-104.

Wijayanti, A., \& Wulandari, T. (2016). Efektivitas Model CTL dan Model PBL Terhadap Hasil Belajar IPS. Harmoni Sosial: Jurnal Pendidikan IPS, 3(2), 112-124.

Wijayanti, T., \& Sugiman. (2013). Keefektifan Pendekatan CTL dan Problem Solving Ditinjau dari Prestasi Belajar Matematika dan Religiusitas Siswa. PYTHAGORAS: Jurnal Pendidikan Matematika, 8(2), 213-223.

Wulandari, D., \& Setyowati, N. (2017). Keefektifan Pendekatan CTL Terhadap Hasil Belajar IPA Materi Sumber Daya Alam. Phenomenon: Jurnal Pendidikan MIPA, 7(1), 50-57.

Yeliherti. (2015). Peningkatan Hasil Belajar Soal Cerita melalui Pendekatan Contextual Teaching and Learning pada Siswa Kelas III SDN 22 Lubuk Alung. JPPI (Jurnal Penelitian Pendidikan Indonesia), 1(1), 47-54.

Yenti, I. N. (2009). Pendekatan Kontekstual (CTL) dan Implikasinya Dalam Pembelajaran Matematika. Ta'dib, 12(2), 118-125.

Yuliani, A. (2015). Meningkatkan Kemampuan Komunikasi Matematik pada Mahasiswa Melalui Pendekatan Contextual Teaching and Learning (CTL). Infinity, 4(1), 1-9.

Yulianti, H., An'nur, S., \& Mustika Wati. (2014). Meningkatkan Hasil Belajar Siswa pada Materi Ajar Listrik Statis Dengan Pendekatan Problem Posing. Berkala Ilmiah Pendidikan Fisika, 2(3), 244-252.

Yulindaria, L., \& Cahyani, I. (2017). Penerapan Pendekatan Contextual Teaching and Learning(CTL) untuk Meningkatkan Hasil Belajar Siswa pada Materi Energi Gerak Dalam Pembelajaran IPA Sekolah Dasar. Metodik Didaktik, 13(1), 33-41.

Yuniarti, N., Sulasmini, L., Rahmadhani, E., Rohaeti, E. E., \& Fitriani, N. (2018). Hubungan Kemampuan Komunikasi Matematis dengan Self Esteem Siswa SMP Melalui Pendekatan CTL pada Materi Segiempat. JNPM (Jurnal Nasional Pendidikan Matematika), 2(1), 6272. 